\author{
Oleg Grynyshyn, Olena Astakhova and Taras Chervinskyy
}

\title{
PRODUCTION OF BITUMEN MODIFIED BY PETROLEUM RESINS ON THE BASIS OF TARS OF UKRAINIAN OILS
}

\author{
Lviv Polytechnic National University, \\ 12 Bandera str., 79013 Lviv, Ukraine \\ mbratych@polynet.Iviv.ua
}

Received: April 05, 2010 / Accepted: M ay 04, 2010

(c) Grynyshyn O., Astakhova O., Chervinskyy T., 2010

\begin{abstract}
Experimental results concerning main regularities of paraffin tar and petroleum resins joint oxidation are presented. It has been shown that petroleum resin in the amount of 5 mas $\%$ as raw material component allows to intensify oxidation and improve operational characteristics of obtained bitumen.
\end{abstract}

Keywords: tar, blown bitumen, petroleum resin, modification, adhesion.

\section{Introduction}

It is well-known that bitumen may be obtained using raw material of definite composition [1-3]. Tars of naphtenearomatic oils may be used for producing of different kinds of bitumen and tars of highly paraffinic oils - only for some kinds of building bitumen [4]. Investigations of paraffin hydrocarbons present in the raw material indicate that they are undesirable components and highly paraffinic oils cannot be used for bitumen production at all [5]. Modification of paraffins is one of the solutions of the mentioned problem. Paraffins in residues of highly paraffinic oils (> $723 \mathrm{~K}$ ) are partially cracked and distilled and partially isomerized transforming into more reactive compounds in the presence of potassium persulfate, manganese acetate or ozone [6]. Another method of paraffins reduction in the raw material is weighting of raw material (tar) owing to the increased runoff of the distillates. At the same time the lower content of paraffin-naphtenic hydrocarbons, the higher ductility of produced bitumen. Tar weighting of also increases the bitumen brittle temperature [7].

It was shown earlier [8] that petroleum resins may be used for bitumen production. They are added in the amount of 3-7 mas \% to the raw material directly before oxidation. The joint oxidation of "Pyroplast-2" petroleum resin and tar obtained from the mix of Russian oils was investigated.
The aim of the present work is to investigate the joint oxidation of petroleum resins and highly paraffinic tar obtained from the Ukrainian oils with further production of high-quality bitumen on their basis.

\section{Experimental}

The tar obtained from West-Ukrainian oils at JSC "Naftokhimik Prykarpattya" (Nadvirna, Ukraine) was used as raw material. Its characteristics are: $d_{4}^{20}=0.989$ and softening temperature determined by ring and ball method $\left(T_{\text {soft }}\right)$ is $308 \mathrm{~K}$.

Three types of petroleum resins (PR) were used:

Dark PR was obtained via thermal polymerization of pyrolysis heavy resin. It is a substance with dark-brown color and softening temperature of $378 \mathrm{~K}$.

Light PS was obtained via thermal oligomerization of $\mathrm{C}_{5}$ and $\mathrm{C}_{9}$ fractions of pyrolysis pyrocondensate. It is a substance with light-yellow color and softening temperature of $355 \mathrm{~K}$.

Pyroplast-2 PS was obtained via thermal oligomerization of $\mathrm{C}_{0}$ fraction. It is a commercial solid product with light-yellow color and softening temperature of $358 \mathrm{~K}$.

The joint oxidation of tar and PS was carried out at the laboratory plant consisting of the reactor block, air supply system, cooling system and unit of oxidation volatile products. The scheme of the laboratory plant is represented in Fig. 1.

Bitumen ductility, penetration, and softening temperature were determined using standard procedures. The "adhesion to glass" index was determined using the procedure described in [1]. Penetration index was determined using standard tables depending on bitumen softening temperature and depth of needle penetration by standard procedure. Bitumen brittle temperature and plastic range were determined by the procedure described in [1]. 


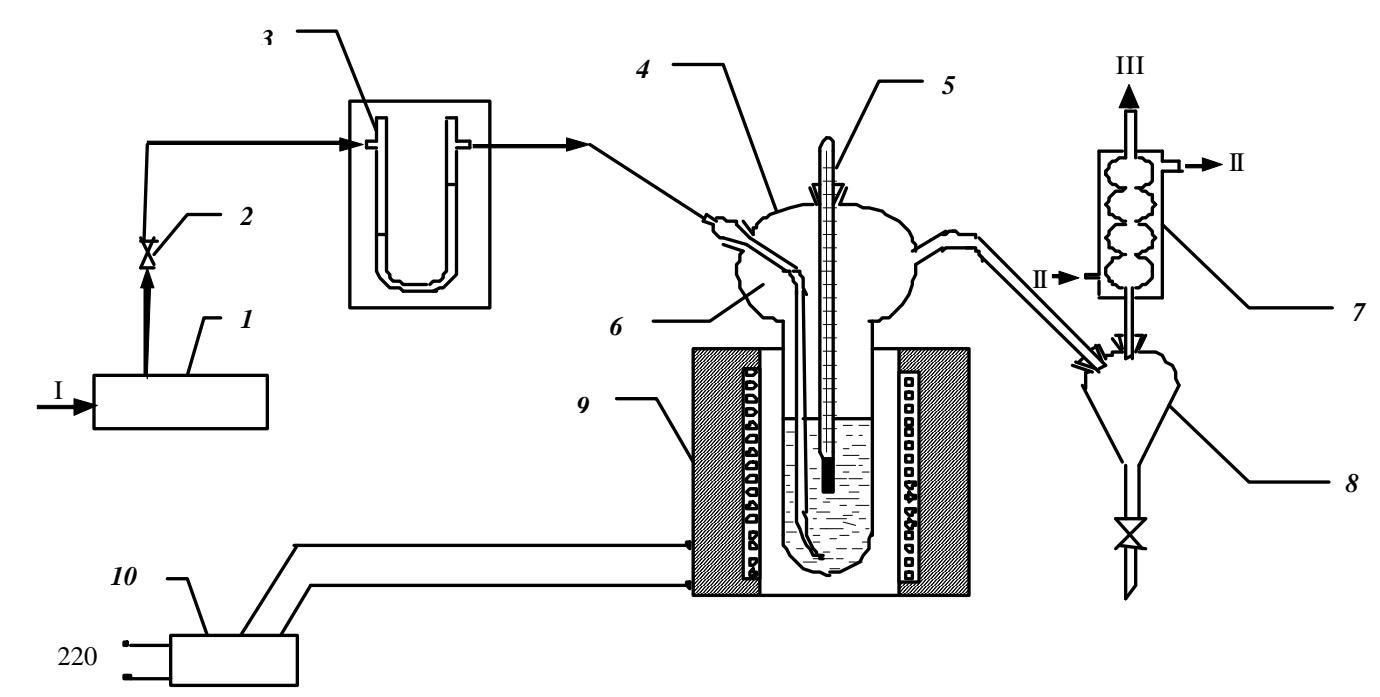

Fig. 1. Laboratory plant for the production of blown bitumen: compressor for air supply (1); expansion cock for air consumption (2); rheometer (3); reactor (4); thermometer (5); capillary (6); refrigerator (7); trap (8); heating furnace (9) and laboratory transformer (10). Flows: air (I), water (II) and oxidation gases (III)

The chemical group composition was determined by Marcusson method [9] using different solubility of resinous-asphaltenes components presented in bitumen. At the analysis initial stage the ability of asphaltenes, carbenes, and carboides to precipitate in low-molecular alkanes is used. After washing of sediment on the filter by benzene which dissolves asphaltenes but does not dissolve carbenes and carboides the content of all mentioned components is determined. The content of oils and resins is determined from solution concentrate using adsorption on silicagel with further desorption by petroleum ether and alcohol-benzene.

\section{Results and Discussion}

\subsection{Effect of Modifier $\mathrm{N}$ ature on the Properties of Blown Bitumen}

In order to establish the efficiency of bitumen modification the joint oxidation of tar and petroleum resins of different type has been studied. The experimental results are presented in Table 1.

It has been established that the introduction of petroleum resins into the raw material essentially affects the characteristics of obtained bitumen. The softening

Effect of PR type on the properties of modified bitumen

\begin{tabular}{|l|c|c|c|c|}
\hline \multicolumn{1}{|c|}{ Index } & Tar without & \multicolumn{3}{c|}{ PR type } \\
\cline { 3 - 5 } & PR & Pyroplast-2 & Light PS & Dark PS \\
\hline $\begin{array}{l}\text { Softening temperature determined by ring } \\
\text { and ball method, K }\end{array}$ & 313 & 320 & 318 & 320 \\
\hline Ductility at 298 K, cm & 13 & 27 & 28 & 25 \\
\hline Penetration at 298 K, 0.1 mm & 188 & 82 & 103 & 91 \\
\hline Penetration index & -0.3 & -0.7 & -0.7 & -0.5 \\
\hline Brittle temperature, K & 241 & 245 & 243 & 247 \\
\hline Plasticity range, K & 72 & 75 & 75 & 73 \\
\hline Adhesion with glass, \% & 33.8 & 61.4 & 47.3 & 47.6 \\
\hline Content in bitumen, mas \%: & & & & 5 \\
$-\quad$ oil components & 62.5 & 56.9 & 53.2 & 58.0 \\
$-\quad$ resins & 24.0 & 27.6 & 30.0 & 24.6 \\
$-\quad$ asphaltenes & 13.5 & 15.5 & 16.8 & 17.4 \\
\hline
\end{tabular}

Note: PR content is 5 mas \%; temperature is $523 \mathrm{~K}$; process time is $6 \mathrm{~h}$; volumetric flow rate is $2.5 \mathrm{~min}^{-1}$. 
temperature, ductility and brittle temperature increase but penetration and penetration index decrease compared with those for bitumen without PR. The plasticity range increases slightly. Using PR as raw material component allows to improve adhesive properties. The increase of "adhesion to glass" index indicates this fact.

The chemical group composition of bitumen obtaining on the basis of tar without additives and PR modified bitumen has been examined. The introduction of PR to the raw material allows to intensify the process. In such case the content of resins and asphaltenes in bitumen increases compared with non-modified bitumen (Table 1). Moreover, there is a clear correlation between asphaltenes content and penetration, as well as between resins content and bitumen ductility.

Comparing the results obtained at bitumen modification by different PRs one can see that bitumens with similar properties are obtained using Pyroplast-2 and light PR. Using dark PS allows to obtain bitumen with higher penetration index. Therefore, we chose dark PS for our further investigations.

\subsection{Effect of Modifier Amount on the Properties of Blown Bitumen}

To establish the optimal content of petroleum resin in the raw material the joint oxidation of tar and dark PS was studied at different tar: PS ratio. The amount of PR was ranged from 2.5 to 7.5 mas $\%$. The oxidation temperature was $523 \mathrm{~K}$, the process time $-6 \mathrm{~h}$. The volumetric flow rate was $2.5 \mathrm{~min}^{-1}$. The experimental results are presented in Table 2.

One can see from Table 2 that the increase of dark PS amount in the mix with tar increases bitumen softening temperature and ductility and decreases bitumen penetration. Such change of parameters correlates with the investigation results of bitumen chemical group composition, namely: the increase of penetration is connected with the increase of asphaltenes amount and the increase of ductility - with the increase of resins amount. The penetration index decreases and the brittle temperature increases with the increase of dark PR amount in the raw material. The increase of dark PR amount increases also the plasticity range and improves adhesion properties of blown bitumen.

Thus, the amount of 5 mas \% of dark PS in the raw material is the optimum one. Such amount improves the operational characteristics of modified bitumen. A greater amount of modifier is inexpedient.

\subsection{Effect of Oxidation Time on the Bitumen Properties}

The effect of oxidation time on the proceeding of joint oxidation was studied using tar and dark petroleum resin. The experiments were carried out at $523 \mathrm{~K}$ and volumetric flow rate $2.5 \mathrm{~min}^{-1}$ for $6-12 \mathrm{~h}$. The results are listed in Table 3.

One can see from Table 3 that the increase of oxidation time increases softening temperature and decreases penetration. The penetration index and brittle temperature increase as well. Such changes in bitumen properties are connected with the changes in the chemical group composition, particularly with the increase of asphaltenes content and decrease of oil components content.

The dependence of resins content in bitumen on oxidation time has extreme character with the maximum at $9 \mathrm{~h}$. The increase of time results in the resins conversion into asphaltenes and their content decreases. Since resins

Effect of dark PR amount on the properties of modified bitumen

Table 2

\begin{tabular}{|l|c|c|c|c|}
\hline \multirow{2}{*}{ Index } & \multicolumn{4}{c|}{ PR amount in the raw material, mas \% } \\
\cline { 2 - 5 } & 0 & 2.5 & 5 & 7.5 \\
\hline $\begin{array}{l}\text { Softening temperature determined by ring } \\
\text { and ball method, K }\end{array}$ & 313 & 315 & 320 & 324 \\
\hline Ductility at 298 K, cm & 13 & 20 & 25 & 31 \\
\hline Penetration at 298 K, 0.1 mm & 188 & 152 & 91 & 59 \\
\hline Penetration index & -0.3 & -0.4 & -0.5 & -0.5 \\
\hline Brittle temperature, K & 241 & 242 & 247 & 250 \\
\hline Plasticity range, K & 72 & 73 & 73 & 74 \\
\hline Adhesion with glass, \% & 27.8 & 34.2 & 47.6 & 60.0 \\
\hline Content in bitumen, mas \%: & & & & \\
$-\quad$ oil components & 62.5 & 59.9 & 58.0 & 55.0 \\
$-\quad$ resins & 24.0 & 24.1 & 24.5 & 26.0 \\
$-\quad$ asphaltenes & 13.5 & 16.0 & 17.4 & 18.9 \\
\hline
\end{tabular}


Effect of oxidation time on the properties of modified bitumen

Table 3

\begin{tabular}{|l|c|c|c|}
\hline \multirow{2}{*}{\multicolumn{1}{|c|}{ Index }} & \multicolumn{3}{c|}{ Oxidation time, $\mathrm{h}$} \\
\cline { 2 - 4 } & 6 & 9 & 12 \\
\hline $\begin{array}{l}\text { Softening temperature determined by ring } \\
\text { and ball method, K }\end{array}$ & 320 & 325 & 328 \\
\hline Ductility at 298 K, cm & 25 & 34 & 28 \\
\hline Penetration at 298 K, 0.1 mm & 91 & 62 & 49 \\
\hline Penetration index & -0.5 & -0.2 & 0 \\
\hline Brittle temperature, K & 247 & 254 & 258 \\
\hline Plasticity range, K & 73 & 71 & 70 \\
\hline Adhesion with glass, \% $\%: ~$ & 47.6 & 52.7 & 61.8 \\
\hline Content in bitumen, mas \%: & 58.0 & 53.0 & 51.2 \\
$-\quad$ oil components & 24.5 & 27.3 & 27.0 \\
$-\quad$ resins & 17.4 & 19.6 & 21.6 \\
$-\quad$ asphaltenes & \multicolumn{2}{|}{} \\
\hline
\end{tabular}

Note: dark PR content is 5 mas \%; temperature is $523 \mathrm{~K}$; volumetric flow rate is $2.5 \mathrm{~min}^{-1}$

content affects the bitumen ductility, this index also increases with the increase of oxidation time, achieves maximum at $9 \mathrm{~h}$ and decreases further. The "adhesion to glass" index increases with the increase of oxidation time; hence adhesion properties of bitumen are improved.

\subsection{Effect of Air Flow Rate on the Properties of Blown Bitumen}

The raw material for investigations were tar and 5 mas $\%$ of dark PS. The volumetric flow rate of air was changed from 2.0 to $3.0 \mathrm{~min}^{-1}$. The results are listed in Table 4.

The increase of air flow rate increases softening temperature and ductility of bitumen. At the same time the bitumen penetration decreases. The increase of penetration index (from- -0.8 to +0.1 ) indicates the increase of oxidation depth at the increase of air flow rate. The mentioned dependencies are in good agreement with the results of group chemical analysis. The increase of air flow rate considerably increases the content of resins and asphaltenes in modified bitumen. The decrease of oils content resulting in the increase of brittle temperature is also observed. The bitumen adhesion is improved with the increase of air flow rate.

\subsection{Effect of Oxidation Temperature on the Bitumen Properties}

The raw material for investigations was the mix of tar and 5 mas $\%$ of dark PS. The process was carried out for $6 \mathrm{~h}$ within the temperature range of 503-543 K. The volumetric flow rate of air was $2.5 \mathrm{~min}^{-1}$. The experimental results are presented in Table 5.
The increase of temperature increases softening temperature of modified bitumen and decreases its penetration. Such change of the main parameters is in agreement with the results of chemical group composition (the increase of temperature increases asphaltenes content and decreases oils content). The dependence of bitumen ductility upon oxidation temperature has an extreme character with the maximum at $523 \mathrm{~K}$. It is connected with the change of resins content in the bitumen. At first the increase of temperature increases resins content but at higher temperatures (> 523 K) this value decreases due to the conversion of resins into asphaltenes. The penetration index decreases and brittle temperature, as well as plasticity range, increase with the increase of temperature. Adhesion properties are improved.

The results obtained during experiments show that the presence of PR in the raw material allows to intensify the oxidation process. It means that under similar conditions in the presence of PR (5 mas \%) it is possible to obtain bitumen with higher softening temperature (by $2-5 \mathrm{~K}$ ), lower penetration (by $85-92.0 .1 \mathrm{~mm}$ ) and higher ductility (by 15-24 cm) compared with those values obtained at oxidation without PR. Due to the presence of PR in the raw material the penetration index decreases by $0.3-0.7$ units, brittle temperature increases by $1-3 \mathrm{~K}$, and plasticity range increases by $2-3 \mathrm{~K}$.

The conducted experiments show principal possibility and advisability of bitumen modification via joint oxidation of tar and petroleum resins. Using PR as raw material component intensifies oxidation process and improves bitumen adhesive properties. The investigated method allows to obtain blown bitumen of high quality from tars of paraffinic oils. 
Effect of air flow rate on the properties of modified bitumen

\begin{tabular}{|l|c|c|c|}
\hline \multirow{2}{*}{\multicolumn{1}{|c|}{ Index }} & \multicolumn{3}{|c|}{ Air flow rate, $\min ^{-1}$} \\
\cline { 2 - 4 } & 2.0 & 2.5 & 3.0 \\
\hline $\begin{array}{l}\text { Softening temperature determined by ring } \\
\text { and ball method, K }\end{array}$ & 315 & 320 & 327 \\
\hline Ductility at 298 K, cm & 24 & 25 & 31 \\
\hline Penetration at 298 K, 0.1 mm & 137 & 91 & 57 \\
\hline Penetration index & -0.8 & -0.5 & 0.1 \\
\hline Brittle temperature, K & 239 & 247 & 258 \\
\hline Plasticity range, K & 76 & 73 & 69 \\
\hline Adhesion with glass, \% & 31.9 & 47.6 & 52.1 \\
\hline Content in bitumen, mas \%: & & & \\
$-\quad$ oil components & 62.1 & 58.0 & 48.8 \\
$-\quad$ resins & 21.8 & 24.5 & 26.1 \\
$-\quad$ asphaltenes & 16.1 & 17.4 & 25.0 \\
\hline
\end{tabular}

Note: dark PR content is 5 mas \%; temperature is $523 \mathrm{~K}$; process time is $6 \mathrm{~h}$

Effect of temperature on the properties of modified bitumen

\begin{tabular}{|l|c|c|c|}
\hline \multirow{2}{*}{ Index } & \multicolumn{3}{|c|}{ Temperature, K } \\
\cline { 2 - 4 } & 503 & 523 & 543 \\
\hline $\begin{array}{l}\text { Softening temperature determined by ring } \\
\text { and ball method, K }\end{array}$ & 316 & 320 & 323 \\
\hline Ductility at 298 K, cm & 21 & 25 & 24 \\
\hline Penetration at 298 K, 0.1 mm & 137 & 91 & 65 \\
\hline Penetration index & -0.4 & -0.5 & -0.6 \\
\hline Brittle temperature, K & 243 & 247 & 249 \\
\hline Plasticity range, K & 73 & 73 & 53.1 \\
\hline Adhesion with glass, \% & 41.9 & 47.6 & 56.3 \\
\hline Content in bitumen, mas \%: & & & 23.9 \\
$-\quad$ oil components & 61.4 & 58.0 & 19.7 \\
\hline$\quad$ resins & 22.4 & 24.5 & 17.4 \\
\hline$\quad$ asphaltenes & 16.2 & & 53 \\
\hline
\end{tabular}

Note: dark PR content is 5 mas \%; process time is $6 \mathrm{~h}$; volumetric flow rate is $2.5 \mathrm{~min}^{-1}$

\section{Conclusions}

The principal possibility of petroleum resins use for the production of blown bitumen on the basis of tars of highly paraffinic oils has been established. The joint oxidation process of tar of paraffinic oils from Ukrainian oilfields and dark petroleum resin has been studied. The optimum PR amount of 5 mas \% has been determined. Using PR as a modifier allows to improve bitumen operational characteristics. The presence of PR intensifies oxidation process and decreases its duration 1.5 to 2 times.

\section{References}

[1] Hoon R.: Neftyanye Bitumy. Khimiya, Moskwa 1973.

[2] Belokon' N., Kompaneec V., Kolpakova A. et al.:

Neftepererabotka i Nefnekhimiya, 2001, 1, 19.

[3] Gohmann L., Guraryi E. and Davydova A.: Khimiya i Technologiya Topliv i Masel, 2008, 6, 35.

[4] Katrenko L. and Kvitkovskyy L.: Visnyk Nats.Univ.

"Lvivska Polytechnica", Lviv 2005.

[5] Richter F.: Bitumen, 2001, 63, 103.

[6] Bayasgulun H., Bembel V., Golovko A. and Shyrchyn B.: Neftepererabotka i Nefnekhimiya, 2008, 7, 17. 
[7] Grynyshyn O., Bratychak M., Krynytskiy V. and Donchak V.: Chem. \& Chem. Techn., 2008, $2,47$.

[8] Isagulyanc V.: Khimiya Nefti. Khimiya, Moskwa 1965.

\section{ОДЕРЖАННЯ НА ОСНОВІ ГУДРОНІВ}

УКРАЇНСЫКИХ НАФТ БТТУМІВ, МОДИФІКОВАНИХ НАФТОПОЛІМЕРНИМИСМОЛАМИ

Анотація. Наведені результати експериментальних досліджень основних закономірностей процесу сумісного окиснення парафінистого гудрону та нафтополімерних смол. Показано, щзо використання нафтополімерної смоли в кількості 5 \% мас. як компонента сировини для виробництва бітумів дає можливість інтенсифікувати процес окиснення та покращуити експлуатаційні характеристики отримуваних нафтових бітумів.

Ключові слова: гудрон, окиснений бітум, нафтополімерна смола, модифікачія, адгезія. 